\title{
Antidiabetic and hypolipidemic effects of adropinin streoptozotocin-induced type 2 diabetic rats
}

\author{
Akcilar $\mathrm{R}^{1}$, Kocak FE ${ }^{2}$, Simsek $\mathrm{H}^{1}$, Akcilar $\mathrm{A}^{3}$, Bayat $\mathrm{Z}^{4}$, Ece $\mathrm{E}^{5}$, Kokdasgil $\mathrm{H}^{5}$ \\ University of Dumlupinar, Faculty of Medicine, Department of Physiology, Kütahya, Turkey. \\ raziyeakcilar@gmail.com
}

\begin{abstract}
BACKGROUND: To examine the effects of adropin on glucose and lipid metabolism in a rat model of Type 2 diabetes mellitus (T2DM).

METHODS: T2DM were established using high-fat diet and streptozocin (STZ; $35 \mathrm{mg} / \mathrm{kg} / \mathrm{b} . \mathrm{w}$.). Seven days after STZ induction, diabetic rats were randomly treated with adropin $(2.1 \mu \mathrm{g} / \mathrm{kg} /$ day intraperitonealy) for 10 days. The study involved the evaluation of biochemical parameters, including blood glucose, total cholesterol (TC), triglycerides (TG), low-density lipoprotein-cholesterol (LDL-C), high-density lipoprotein-cholesterol (HDL-C), aspartate transaminase (AST), alanine transaminase (ALT), alkaline phosphatase (ALP) and gamma glutamyl transferase (GGT) activities. Additionally, Tumor necrosis factor-alpha (TNF- $\alpha$ ), interleukin 6 (IL-6) and inducible nitric oxide synthase (iNOS) mRNA gene expressions in pancreas tissue were determined

by reverse transcription-polymerase chain reaction.

RESULTS: The serum levels of insulin and adropin were determined by ELISA. Treatment with adropin showed a significant reduction in blood glucose levels, HbA1c (\%), HOMA-IR and increase in HOMA- $\beta$, serum insulin levels. In addition, intraperitoneal adropin application can reduce serum levels of TC, TG, LDL-C, and increase level of HDL-C. Adropin also effectively ameliorated the alterations in TNF- $\alpha$, IL- 6 and iNOS mRNA expression. CONCLUSION: The present study indicates that the adropin possesses antidiabetic and antidyslipidemic effects in T2DM (Tab. 2, Fig. 3, Ref. 32). Text in PDF www.elis.sk.

KEY WORDS: adropin, type 2 diabetic rat, blood glucose, insulin, high fat diet.
\end{abstract}

\section{Introduction}

Diabetes mellitus is a common metabolic syndrome affecting more than 170 million individuals worldwide (1), among which $\sim 90 \%$ are classified as type 2 diabetes (2). Insulin resistance, arising primarily in peripheral tissue and liver, is the main reason accounting for hyperglycemia in obesity and type 2 diabetes (2). Thus, understanding the regulation of the insulin response and identifying the related mechanisms are important to early treatment and prevention of type 2 diabetes mellitus.

A new metabolic hormone, adropin, was isolated in 2008 by Kumar et al where the coding Enho gene (energy homeostasis associated) was found to be expressed in the liver and the brain of

${ }^{1}$ University of Dumlupinar, Faculty of Medicine, Department of Physiology, Kütahya, Turkey, ${ }^{2}$ University of Dumlupinar, Faculty of Medicine, Department of Biochemistry, Kütahya, Turkey, ${ }^{3}$ University of Dumlupinar, Faculty of Medicine, Experimental Animal Research Center, Kütahya, Turkey, ${ }^{4}$ University of Dumlupinar, Faculty of Arts and Sciences, Department of Biochemistry, Kütahya, Turkey, and ${ }^{5}$ University of Dumlupinar, Faculty of Arts and Sciences, Department of Biology, Kütahya, Turkey

Address for correspondence: R. Akcilar, Dumlupinar University, Medical Faculty, Department of Physiology, Kütahya, Turkey.

Phone: +90.507.9539474, Fax: +90.274.2652285

Acknowledgments: The authors are grateful to Dumlupinar Research Centre (DPU-ILTEM) for using the laboratory and equipments, to Didem Ocak and Arif Soylu for their help in experimental research. mice (3). Celik et al (4) showed that the mean maternal and cord serum adropin concentration is lower in women with gestational diabetes mellitus than controls. Kumar et al have also indicated an association between adropin deficiency, increased adiposity, and insulin resistance (3). Adropin could therefore be a factor regulating glucose and lipid homeostasis, which protects against the hepatosteatosis and hyperinsulinemia associated with obesity. This peptide is expressed in rat brain, cerebellum, kidneys, heart, liver, and pancreas and its levels are increased in streptozotocininduced diabetes (5).

Adropin is a highly conserved polypeptide that has been suggested to act as an endocrine factor that plays important roles in metabolic regulation, insulin sensitivity, and endothelial functions. Adropin is an established modality in the treatment of T2DM although their effects and functions are still unclear. Literature information showing the relationship between adropin and T2DM is very limited. Therefore, we hypothesized a possible curative effect of adropin, which we examined on rats with type 2 diabetes induced by high fat-diet and streptozotocin.

\section{Materials and methods}

\section{Animals}

Twenty four adult female Wistar albino rats (Dumlupinar University Experimental Animal Laboratory, Kütahya, Turkey) weighing 250-300 g were used. All rats were kept under envi- 
ronmentally controlled conditions in an air-conditioned room at $21{ }^{\circ} \mathrm{C}$, with appropriate humidity and a $12 \mathrm{~h}: 12 \mathrm{~h}$ light: dark cycle and were fed standard rat chow and water ad libitum. This project was approved by the Dumlupinar University Ethics Committee of Animal Care and Usage, Kütahya, Turkey.

\section{Induction of experimental diabetes}

Diabetes was induced in rats by orally feeding them with high fat emulsion (10 mL/kg) (6) for 2 weeks. After 2 weeks, the animals were kept in an overnight fast and injected with single dose STZ (35 mg/kg body weight in $0.1 \mathrm{M}$ citrate buffer $\mathrm{pH} 4.5$, intraperitonealy) (7). One week after the STZ injection, the nonfasting blood glucose levels of all animals were measured in the blood collected from the tail vein by using a portable glucometer (eBsensor, Turkey). The animals with blood glucose levels higher than $300 \mathrm{mg} / \mathrm{dL}$ were accepted for inclusion as diabetic.

\section{Experimental design}

The female animals were selected randomly and divided into three experimental groups of eight animals each: Group I served as the control (C) receiving saline as vehicle. Group II diabetic rats (D) served as the diabetic control rats. Group III (DA); diabetic rats were treated with adropin at a dosage of $2.1 \mu \mathrm{g} / \mathrm{kg} /$ day intraperitonealy for 10 days.

\section{Tissue preparation and blood sampling}

At the end of the experimental period, all animals were anesthetized with Ketamin/Xylazine $\mathrm{HCl}(75 \mathrm{mg} / \mathrm{kg} / 10 \mathrm{mg} / \mathrm{kg}$ intraperitoneally). Blood sample was collected from the aorta in a glass tube to clot for $2 \mathrm{~h}$ at room temperature and centrifuged for $20 \mathrm{~min}$ to obtain serum for insulin and adropin analysis. Serum was stored at $-80{ }^{\circ} \mathrm{C}$. Pancreas tissue samples were then collected in liquid nitrogen for analysis of molecular biologic studies, and stored at $-80{ }^{\circ} \mathrm{C}$ until analysis.

\section{Biochemical analyses}

Serum concentrations of insulin and adropin were analyzed with rat ELISA assay kit using the chemiluminescence method (Cusabio, China) according to the instruction of manufacturer by the ELISA microplate reader (Spectrostar Nano, BMG, Labtech, Germany). The serum concentrations of TC, TG, HDL-C, LDL$\mathrm{C}, \mathrm{AST}$, ALT, ALP and GGT activities were measured by using the Beckman Coulter AU680 analyzer (Beckman Coulter, Miami, FL, USA).

For glycosylated hemoglobin A1c (HbA1c,\%) measurements, blood samples were collected into $2.0 \mathrm{~mL}$ dipotassium (K2) ethylene diamine tetraacetic acid (EDTA) vacuum tubes (BD Vacuteiner ${ }^{\circledR}$ BD-Plymouth, UK). After blood samples were collected, HbA1C measurement was immediately performed without a delay. Measurement of HbA1C was performed on Tosoh G8 HPLC Analyzer (Tosoh Bioscience, Inc., San Francisco, CA).

Homeostatic model assessment (HOMA-IR) score was calculated using fasting serum insulin and fasting blood glucose concentrations measured at the end of the experimental period according to the following formula: HOMA-IR [(Fasting serum insulin in $\mathrm{U} / \mathrm{L} \mathrm{X}$ fasting blood glucose in $\mathrm{mmol} / \mathrm{L}) / 22.5]$. $\beta$-cell function was quantified with the HOMA- $\beta$, with the formula [serum insulin $(\mathrm{U} / \mathrm{L}) \times 20 /$ glucose $(\mathrm{mmol} / \mathrm{L})-3.5](8)$.

\section{Reverse transcriptase polymerase chain reaction (RT-PCR)}

Total RNA isolation was extracted from pancreas tissue samples by the GeneJET RNA Purification Kit (Thermo, Cat No: \# K0732) according to the manufacturer's protocol. Total mRNA concentrations were measured at $260 \mathrm{~nm}$ using a Maestro Nano Micro-Volume spectrophotometer (Maestrogen Inc., Las Vegas, $\mathrm{NV}$ ). Samples were stored at $-80^{\circ} \mathrm{C}$ until further analysis. Complementary DNAs (cDNA) were synthesized by EasyScript ${ }^{\mathrm{TM}}$ cDNA Synthesis Kit (abm). cDNAs were stored at $-20{ }^{\circ} \mathrm{C}$ until used in the RT-PCR

PCR was carried out in a total volume of $25 \mu 1$ containing DNA template, 10XPCR-buffer, PCR grade $\mathrm{H}_{2} \mathrm{O}, 25 \mathrm{mmol} / \mathrm{L} \mathrm{MgCl}_{2}$ and $10 \mathrm{mmol} / \mathrm{L}$ concentration of primers. RT-PCR was performed according to the manufacturer's instructions. The forward and reverse primers for TNF- $\alpha$ were 5 '-CCA CCA CGC TCT TCT GTC TAC-3' and 5'-GCT ACG GGC TTG TCA CTC G-3', 148 bp, for IL-6 were 5'-CTT CCA GCC AGT TGC CTT CTT G-3' and 5'-TGG TCT GTT GTG GGT GGT ATC C-3', 109 bp, for iNOS were 5'-TTG GAG CGA GTT GTG GAT TGT TGT TC-3' and 5'-GGT GAG GGC TTG CCT GAG TG AGC-3', 126 bp. As a control for the presence of amplifiable RNA, $\beta$-actin primers were designed. The forward and reverse primers for $\beta$-actin were 5'-CTA TCG GCA ATG AGC GGT TCC -3' and 5'-TGT GTT GGC ATA GAG GTC TTT ACG -3', $147 \mathrm{bp}$. The PCR products were electrophoresed in $2 \%$ agarose gel and stained with ethidium bromide, making sure to include DNA markers of appropriate size. The densitometry of each PCR band was measured and analyzed by the image $\mathrm{J}$ program. Optical density was calculated for gene products and results were expressed as the ratio of the density of TNF- $\alpha$, IL-6, iNOS mRNA to $\beta$-actin mRNA.

\section{Statistical analysis}

Statistical analysis was done with the SPSS (Statistical Package for Social Sciences, Chicago, IL, USA) 16.0 pocket program. All results were given as the mean \pm standard error (SE). Comparisons among multiple groups were done with the Kruskal-Wallis test, and between the two groups with the Mann-Whitney U test. Values lower than $\mathrm{p} \leq 0.05$ were accepted as statistically significant.

\section{Results}

Effect of adropin on blood glucose, HbAlc (\%), HOMA-IR, HOMA- $\beta$, serum insulin and adropin levels

Table 1 depicts the levels of blood glucose, HbA1c (\%), HOMA-IR, HOMA- $\beta$, serum insulin and adropin of C, D and DA groups of rats. There were statistically significant differences in blood glucose, HbA1c (\%), HOMA-IR, HOMA- $\beta$ and adropin levels among the groups $\mathrm{C}, \mathrm{D}$ and $\mathrm{DA}(\mathrm{p}<0.05)$. The diabetic rats showed a significant $(p<0.05)$ increase in the levels of glucose, HbAlc (\%), HOMA-IR, while a reduction in HOMA- $\beta$ and adropin levels was comparable with $\mathrm{C}$ and DA groups. Significant differ- 


\section{0-105}

Tab. 1. Effect of adropin on blood glucose, HbA1c (\%), HOMA-IR, HOMA- $\beta$, serum insulin and adropin levels of Control (C), Diabetes (D) and Diabetes + Adropin (DA) groups.

\begin{tabular}{lcccc}
\hline Groups & $\mathrm{C}(\mathrm{n}=8)$ & $\mathrm{D}(\mathrm{n}=8)$ & $\mathrm{DA}(\mathrm{n}=8)$ & $\mathrm{p}$ \\
\hline Blood glucose $(\mathrm{mg} / \mathrm{dl})$ & $77.0 \pm 6.47^{\mathrm{ab}}$ & $412.7 \pm 21.4^{\mathrm{ac}}$ & $224.3 \pm 13.3^{\mathrm{bc}}$ & 0.000 \\
Insulin $(\mathrm{nIU} / \mathrm{ml})$ & $102.1 \pm 11.5$ & $80.1 \pm 9.00^{\mathrm{a}}$ & $123.2 \pm 22.6^{\mathrm{a}}$ & 0.183 \\
HbA1c (\%) & $1.07 \pm 0.03^{\mathrm{a}}$ & $2.26 \pm 0.16^{\mathrm{ab}}$ & $1.27 \pm 0.25^{\mathrm{b}}$ & 0.002 \\
HOMA-IR & $19.9 \pm 3.33^{\mathrm{ab}}$ & $83.3 \pm 12.5^{\mathrm{ac}}$ & $59.4 \pm 15.8^{\mathrm{bc}}$ & 0.001 \\
HOMA- $\beta$ & $6710.4 \pm 2447.9^{\mathrm{ab}}$ & $82.7 \pm 7.28^{\mathrm{ac}}$ & $238.1 \pm 60.5^{\mathrm{bc}}$ & 0.000 \\
Adropin $(\mathrm{ng} / \mathrm{ml})$ & $34.6 \pm 3.57^{\mathrm{a}}$ & $25.7 \pm 1.03^{\mathrm{ab}}$ & $40.3 \pm 4.07^{\mathrm{b}}$ & 0.003 \\
\hline
\end{tabular}

$\mathrm{p}$ - shows the differences between all groups (Kruskal-Wallis test), ${ }^{\mathrm{a}, \mathrm{b}, \mathrm{c}}-$ in each line, the differences between the mean with the same letters are significant, $\mathrm{p} \leq 0.05$ (MannWhitney U test).

Tab. 2. Effect of adropin on lipids and liver enzyme markers of Control (C), Diabetes (D) and Diabetes + Adropin (DA) groups.

\begin{tabular}{lcccc}
\hline Groups & $\mathrm{C}(\mathrm{n}=8)$ & $\mathrm{D}(\mathrm{n}=8)$ & $\mathrm{DA}(\mathrm{n}=8)$ & $\mathrm{p}$ \\
\hline Total Cholesterol $(\mathrm{mg} / \mathrm{dl})$ & $68.0 \pm 5.06^{\mathrm{a}}$ & $92.8 \pm 7.68^{\mathrm{ab}}$ & $66.8 \pm 5.56^{\mathrm{b}}$ & 0.030 \\
Triglycerides (mg/dl) & $127.0 \pm 20.7^{\mathrm{a}}$ & $339.2 \pm 81.5^{\mathrm{ab}}$ & $84.5 \pm 20.4^{\mathrm{b}}$ & 0.004 \\
HDL-C (mg/dl) & $63.3 \pm 5.88^{\mathrm{ab}}$ & $28.1 \pm 3.11^{\mathrm{ac}}$ & $43.0 \pm 4.57^{\mathrm{bc}}$ & 0.002 \\
LDL-C (mg/dl) & $23.2 \pm 2.59$ & $27.5 \pm 2.02^{\mathrm{a}}$ & $18.0 \pm 2.18^{\mathrm{a}}$ & 0.046 \\
AST (U/L) & $143.5 \pm 10.5^{\mathrm{ab}}$ & $196.2 \pm 12.5^{\mathrm{ac}}$ & $82.3 \pm 5.65^{\mathrm{bc}}$ & 0.000 \\
ALT (U/L) & $63.5 \pm 6.00^{\mathrm{ab}}$ & $71.5 \pm 2.35^{\mathrm{ac}}$ & $26.7 \pm 4.91^{\mathrm{bc}}$ & 0.000 \\
ALP (U/L) & $200.7 \pm 19.8^{\mathrm{a}}$ & $414.1 \pm 78.5^{\mathrm{a}}$ & $320.2 \pm 75.8$ & 0.063 \\
GGT (U/L) & $1.25 \pm 0.16^{\mathrm{a}}$ & $9.75 \pm 2.52^{\mathrm{ab}}$ & $5.75 \pm 2.67^{\mathrm{b}}$ & 0.001 \\
\hline
\end{tabular}

AST - aspartate transaminase, ALT - alanine transaminase, ALP - alkaline phosphatase, GGT - gama glutamyl transferase, $\mathrm{p}$ - shows the differences between all groups (Kruskal-Wallis test), ${ }^{\mathrm{a}, \mathrm{b}, \mathrm{c}}-$ in each line, the differences between the mean with the same letters are significant, $\mathrm{p} \leq 0.05$ (Mann-Whitney U test).

ences were not observed in the levels of serum insulin among the groups $\mathrm{C}, \mathrm{D}$ and $\mathrm{DA}(\mathrm{p}=0.183)$. In addition, low levels of serum insulin were not significant in the $\mathrm{D}$ group compared to $\mathrm{C}$ group, but were significant compared to DA group.

Adropin treatment resulted in a decrease in the blood glucose level when compared to diabetic rats. The serum insulin level was statistically significant higher in the DA group than in the D group $(\mathrm{p}=0.05)$. And, also adropin treatment resulted in the improvement in the aberrations in HbA1c (\%), HOMA-IR and HOMA- $\beta$. In addition, it was observed that serum adropin was significantly higher in the DA group compared to the D group.

\section{Effect of adropin on lipids and liver enzyme markers}

Table 2 depicts the levels of serum TC, TG, HDL-C, LDL-C, AST, ALT, ALP, GGT activities of C, D and DA groups of rats.

There were statistically significant differences in serum TC, TG, HDL-C and LDL-C levels among the groups of C, D and DA $(p=0.030, p=0.038, p=0.008$ and $p=0.046)$. The low level of HDL-C was found in the D and DA groups compared to the $\mathrm{C}$ group ( $\mathrm{p} \leq 0.05)$. However, the levels of serum TC, TG in the D group were significantly higher than in the $\mathrm{C}$ and DA groups $(\mathrm{p} \leq$ 0.05 ). A significant decrease in serum TC, TG, LDL-C levels ( $p$ $=0.021, \mathrm{p}=0.002$ and $\mathrm{p}=0.021)$ and a significant increase in the HDL-C levels $(p=0.038)$ were observed in the DA group when compared to D group (Tab. 2).

There were statistically significant differences in serum AST and ALT levels among the groups of C, D and DA ( $p=0.000$ and $p=0.000)$. The level of serum AST and ALT was increased significantly $(\mathrm{p} \leq 0.05)$ in the $\mathrm{D}$ group. Treatment with the adropin resulted in a significant decrease in serum AST and ALT levels (Tab. 2).

The differences in the serum ALP among the C, D and DA groups were not significant $(p=0.063)$. However, the level of serum ALP in the D group was significantly higher than in the $\mathrm{C}$ group $(p=0.015)$. There were statistically significant differences in serum GGT levels among the groups of C, D and DA $(p=0.001)$. In addition, the level of serum GGT was increased significantly $(\mathrm{p} \leq 0.05)$ in the D group. Treatment with the adropin resulted in a significant decrease in serum GGT levels (Tab. 2).

Levels of TNF- $\alpha, I L-6$ and $i N O S$ gene $m R N A$ expression in the pancreas tissue

Figure 1 shows the mRNA expression of TNF- $\alpha$ in the pancreas of C, D and DA groups. The differences in the TNF- $\alpha$ gene mRNA expression levels in the pancreas tissue among $\mathrm{C}(0.91 \pm$ $0.09)$, D (2.24 \pm 0.74$)$ and DA $(0.87 \pm 0.09)$ groups were significant $(p=0.014)$. The expression of TNF- $\alpha$ was increased in the

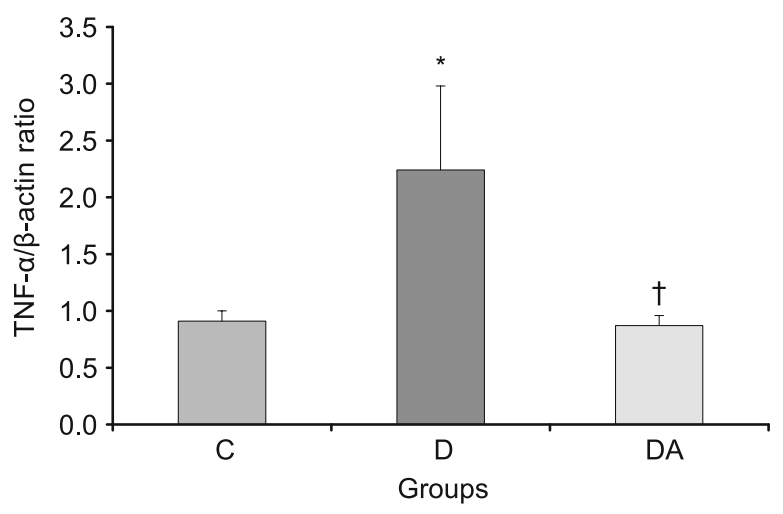

Fig. 1. TNF- $\alpha / \beta$-actin ratio in Control (C), Diabetes (D), Diabetes + Adropin (DA) groups. *; Shows significance between $\mathrm{C}$ and $\mathrm{D}$ groups ( $\leq$ 0.05) (Mann-Whitney $U$ test). $\dagger$; Shows significance between $D$ and DA groups ( $\leq \mathbf{0 . 0 5})$ (Mann-Whitney $U$ test). (TNF- $\alpha$ : Tumor necrosis factor-alpha). 


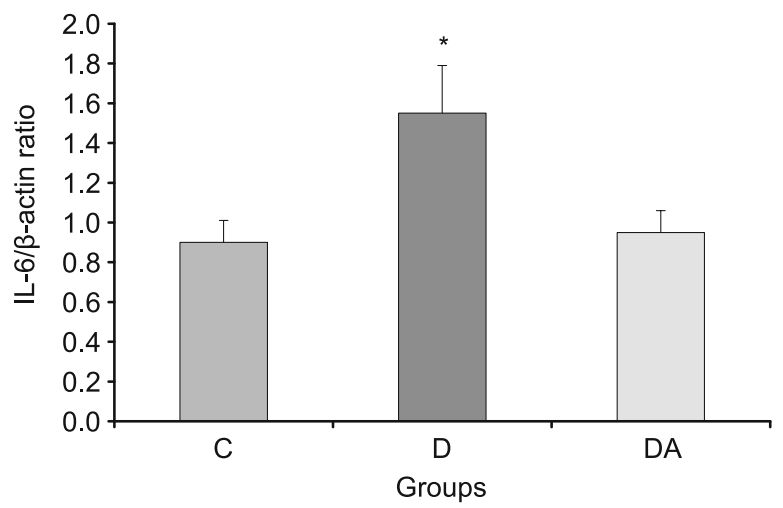

Fig. 2. IL-6/ $\beta$-actin ratio in Control (C), Diabetes (D), Diabetes + Adropin (DA) groups. *; Shows significance between $C$ and $D$ groups $(p \leq$ 0.05) (Mann-Whitney U test). (IL-6: Interleukin 6).

$\mathrm{D}$ group when compared to the $\mathrm{C}$ and DA groups, which were $\mathrm{p}$ $=0.017$ and $\mathrm{p}=0.007$, respectively.

The changes in the level of mRNA expression of IL-6 in the pancreas of the C, D and DA groups are shown in Figure 2. There were significant differences in IL-6 gene mRNA expression levels in the pancreas tissue among the $\mathrm{C}(0.90 \pm 0.11), \mathrm{D}(1.55 \pm$ $0.24)$, DA $(0.95 \pm 0.11)$ groups, $(p=0.046)$. The level of mRNA expression of IL- 6 in the pancreas tissue was increased significantly $(\mathrm{p}=0.017)$ in the $\mathrm{D}$ group compared to the $\mathrm{C}$ group.

Figure 3 shows the mRNA expression of iNOS in the pancreas of the C, D and DA groups. There were significant differences in iNOS gene mRNA expression levels in the pancreas tissue among the $\mathrm{C}(1.41 \pm 0.18), \mathrm{D}(2.29 \pm 0.36)$, DA $(0.95 \pm 0.11)$ groups, ( $=0.007)$. The expression of iNOS was increased in the D group when compared to the $C$ and DA groups $(p=0.038$ and $p=0.007)$. The iNOS gene mRNA expression levels in the DA group were significantly lower than in the $\mathrm{C}$ and $\mathrm{D}$ groups, which were $\mathrm{p}=$ 0.05 and $p=0.007$, respectively.

\section{Discussion}

Type 2 diabetes mellitus is the most common form of the metabolic disorder, which is caused by an impaired insulin secretion paralleled by a progressive decline in $\beta$ cell function and chronic insulin resistance (9). Insulin resistance and $\beta$ cell dysfunction are the important characteristics of T2DM. In addition, the pathogenesis of T2DM was very complicated and associated with insulin resistance and secretion deficiency (10), inflammatory reaction (11), and oxidative stress (12). Therefore, we studied the effect of adropin on blood glucose and insulin levels and also performed HOMA-IR and HOMA- $\beta$ to check the degree of insulin resistance and beta cell function.

In this study, a significant increase was observed in the proportion of blood glucose HbA1c (\%) and HOMA-IR scores, while HOMA- $\beta$ was decreased in STZ-treated type 2 diabetic rats. In addition, there were no significant decreases in the serum level of insulin in the D group compared to the $\mathrm{C}$ and DA groups. In the study by Mahmoud et al (13), it was observed that type 2 diabetic

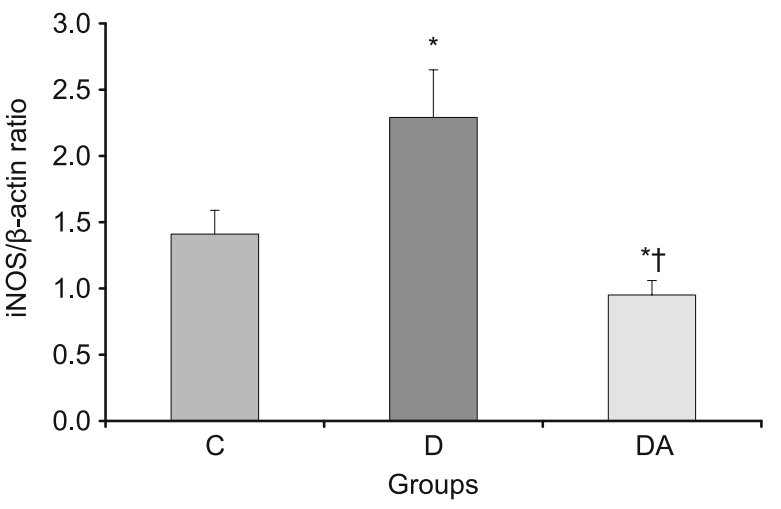

Fig. 3. iNOS/ß-actin ratio in Control (C), Diabetes (D), Diabetes + Adropin (DA) groups. *; Shows significance between D and DA groups with $\mathrm{C}$ group $(\mathrm{p} \leq \mathbf{0 . 0 5})($ Mann-Whitney $\mathrm{U}$ test $)$. $\uparrow$; Shows significance between $D$ and $D A$ groups $(p \leq 0.05)$ (Mann-Whitney $U$ test). (iNOS: inducible nitric oxide synthase).

rats exhibited a significantly elevated fasting blood glucose and HOMA-IR, accompanied with diminished serum insulin levels, and insulin resistance has developed in these animals (13). Huang et al (14) reported that $\mathrm{HbAlc}(\%)$ levels, the indicator of diabetes, were significantly increased in type 2 diabetes mellitus rats (14). Estimation of $\mathrm{HbA} 1 \mathrm{c} \%$ has been found to be particularly useful in monitoring the effectiveness of therapy in diabetes (15). These results seem to be compatible with our study results and can be considered as the indicator of forming type 2 diabetes in rats.

In this study, serum adropin levels were significantly reduced in the D group compared to the $\mathrm{C}$ and DA groups. Wu et al (16) have demonstrated that serum adropin level was significantly lower in type 2 diabetic patients compared to non-diabetic patients. Celik et al (4) showed that mothers with gestational diabetes had lower adropin concentrations in their blood (4). Previous study has shown that (5) adropin is expressed in various tissues as pancreas, liver, kidney, heart in the rats and its levels increased in STZ-induced diabetes. In this study, the expression of adropin in rat pancreas tissues was not considered.

In our study, intraperitonel administration of adropin significantly decreased the levels of fasting blood glucose, HOMA-IR and HbA1c (\%) and increased the levels of HOMA- $\beta$, serum insulin and adropin in the DA group. Yildirim et al (17) recently showed that serum adropin level was negatively correlated with fasting serum insulin levels, HOMA-IR in polycystic ovarian syndrome patients $(\mathrm{p}<0.05)$. Aydin et al $(18)$ reported that there was a negative correlation between $\mathrm{HbA} 1 \mathrm{c}(\%)$ and adropin concentrations. The study demonstrated that lower adropin levels were associated with insulin resistance in humans, as was the case in mice (19). In the study performed by Kumar (3), it was shown that elevated amounts of adropin in circulation reduced insulin resistance and glucose intolerance that occured in response to metabolic stress (3). These results indicated the beneficial effects of adropin in preventing the diabetic complications caused by an impaired glucose metabolism.

In our study, significant decrease in HDL-C levels and a significant increase in the serum TC, TG, LDL-C levels were ob- 


\section{0-105}

served in the D group when compared to the DA group. In the studies performed on type 2 diabetic rats, upregulation of TC, TG, LDL-C levels and downregulation of HDL-C levels were reported when compared to the control group $(20,21)$. After the treatment of adropin, it was found that adropin could remarkably lower the levels of fasting blood glucose, TC, TG and LDL-C, while could also increase the level of HDL-C in the DA group. The previous study by Bulter et al (22) demonstrated that adropin levels correlated negatively with TG in metabolic syndrome patients after a gastric bypass surgery (22). Yildirim et al (17) recently showed that serum adropin level was correlated negatively with serum lipid markers including cholesterol, very low-density lipoprotein, and triglycerides in PCOS patients $(\mathrm{p}<0.05)$. Our present results demonstrated that adropin could decrease the elevated activity of lipids in type 2 diabetic rats. This may be beneficial in the amelioration of the type 2 diabetic state.

In our study, the elevated activities of AST, ALT, ALP and GGT shown in diabetic rats significantly decreased in diabetic rats upon intraperitoneal treatment with adropin. Several researchers reported that the elevated activities of AST, ALT and ALP enzymes were indicative of cellular damage and loss of the functional integrity of the cell membranes $(23,24)$. Soufi et al $(25)$ depicted that levels of hepatic marker enzymes as AST, ALT and ALP in diabetic rats were increased. After the treatment of adropin, it was found that adropin could decrease the level of AST, ALT, ALP and GGT in the DA group. There has not been any study in literature between adropin and hepatic marker enzymes that can be compared with the results of this study. Our present results demonstrated that adropin could decrease the elevated AST, ALT, ALP and GGT activities and had potential hepatoprotective effects in type 2 diabetic rats.

In this study, TNF- $\alpha$ and IL- 6 mRNA expression in the pancreas tissue was significantly increased in the D group compared to the $\mathrm{C}$ group. Liu et al (26) demonstrated that serum TNF- $\alpha$ and IL-6 levels also showed a significant increase in T2DM rats. Earlier workers reported that elevated levels of TNF- $\alpha$ and IL- 6 caused insulin resistance and had a direct cytotoxic effect on pancreatic $\beta$-cells in T2DM $(27,28)$. This study's results are compatible with the aforementioned study. Adropin appeared to inhibit expression of inflammatory cytokines in pancreas, such as TNF- $\alpha$ and IL- 6 in the DA group. There was no study in literature between adropin, TNF- $\alpha$ and IL-6 that could be compared with the results of this study. In the animal study conducted in 2010, Lovren et al (29) reported that adropin-treated endothelial cells demonstrated a higher proliferation, migration, and capillary-like tube formation as well as lower permeability and tumour necrosis factor-alpha-induced apoptosis (29).

In this study, iNOS mRNA expression in the pancreas tissue was significantly increased in the $\mathrm{D}$ group compared to the $\mathrm{C}$ group. The study by Kataoka et al (30) showed that the expression of both iNOS and the TNF- $\alpha$, IL-6 mRNA levels increased in rats with type 2 diabetes mellitus. He et al (31) indicated that the expression of iNOS was increased in the pancreas in STZ-induced diabetic rats. A significant decrease in the iNOS mRNA expression in the DA group was seen when compared to the $\mathrm{C}$ and $\mathrm{D}$ groups. Kuloglu et al (32) showed that the intensities of adropin and iNOS immunoreactivity increased with the severity of the diabetes. In addition, the elevated levels of adropin and iNOS in the kidney indicated that these substances were involved in the pathophysiology of diabetes; this constitutes a compensatory mechanism against the damage inflicted by the disease (32). An increased expression of TNF- $\alpha$, IL- 6 and iNOS mRNA seen in diabetic rats was decreased in adropin treated rats. This showed the activity of the adropin in improving the insulin sensitivity. Our present results demonstrated that adropin suppressed inflammation effects in type 2 diabetic rats.

In conclusion, adropin exhibited a significant antidiabetic activity, presumably by inhibiting inflammatory cytokines, improving glucose metabolism, insulin sensitivity and serum lipid and liver enzyme markers in high fat diet + streptozotocin induced type 2 diabetic model and might be a potential target for diabetes treatment.

\section{References}

1. Brem H, Tomic-Canic M. Cellular and molecular basis of wound healing in diabetes. J Clin Invest 2007; 117: 1219-1222.

2. Kahn SE, Hull RL, Utzschneider KM. Mechanisms linking obesity to insulin resistance and type 2 diabetes. Nature 2006; 444: 840-846.

3. Kumar KG, Trevaskis JL, Lam DD, Sutton GM, Koza RA, Chouljenko VN et al. Identification of adropin as a secreted factor linking dietary macronutrient intake with energy homeostasis and lipid metabolism. Cell Metab 2008; 8: 468-481.

4. Celik E, Yilmaz E, Celik O, Ulas M, Turkcuoglu I, Karaer A et al. Maternal and fetal adropin levels in gestational diabetes mellitus. J Perinat Med 2013; 41: 375-380.

5. Aydin S, Kuloglu T, Aydin S, Eren MN, Yilmaz M, Kalayci M et al. Expression of adropin in rat brain, cerebellum, kidneys, heart, liver, and pancreas in streptozotocin-induced diabetes. Mol Cell Biochem 2013; 380: 73-81.

6. Ai J, Wang N, Du J, Yang M, Liu P, Du Z et al. Establishment of type 2 diabetic animal model in in Wistar rats. Chin Pharmacol Bull 2004; 20: 1309-1312.

7. Srinivasan K, Viswanad B, Lydia Asrat CL Kaul, Ramarao P. Combination of high-fat diet fed and low-dose streptozotocintreated rat: A model for type 2 diabetes and pharmacological screening. Pharm Res $2005 ; 52: 313-320$.

8. Ibrahim MA, Islam MS. Anti-diabetic effects of the acetone fraction of Senna singueana stem bark in a type 2 diabetes rat model. J Ethnopharmacol 2014; 28; 153(2): 392-399.

9. Lupi R, Del Prato S. $\beta$-cell apoptosis in type 2 diabetes: quantitative and functional consequences. Diabet Metab 2008; 34: 56-64.

10. Wild S, Roglic G, Green A, Sicree R, King H. Global prevalence of diabetes: estimates for the year 2000 and projections for 2030. Diabetes Care 2004; 27-5: 1047-1053.

11. Fujita T, Hemmi S, Kajiwara M et al. Complement-mediated chronic inflammation is associated with diabetic microvascular complication. Diabet Metab Res Rev2013; 29 (3): 220-226.

12. Roesen P, Ferber P, Tschoepe D. Macrovascular disease in diabetes: current status. Exp Clin Endocrinol Diabet 2001; 109 (2): S474-S486.

13. Mahmoud AM, Ashour MB, Abdel-Moneim A, Ahmed OM. Hesperidin and naringin attenuate hyperglycemia-mediated oxidative stress and proinflammatory cytokine production in high fat fed/streptozotocininduced type 2 diabetic rats. J Diabet Compl 2012; 26 (6): 483-490. 
14. Huang S, Peng W, Jiang X, Shao K, Xia L, Tang Y, Qiu J. The effect of chromium picolinate supplementation on the pancreas and macroangiopathy in type II diabetes mellitus rats. J Diabet Res 2014; 2014: 717219.

15. Goldstein DE. How much do you know about glycated hemoglobin testing. Clin Diabet 1995; 13: 60-63.

16. Wu L, Fang J, Chen L, Zhao Z, Luo Y, Lin C, Fan L. Low serum adropin is associated with coronary atherosclerosis in type 2 diabetic and non-diabetic patients. Clin Chem Lab Med 2014; 52 (5): 751-758.

17. Yildirim B, Celik O, Aydin S. Adropin: a key component and potential gatekeeper of metabolic disturbances in policystic ovarian syndrome. Clin Exp Obstet Gynecol 2014; 41 (3): 310-312.

18. Aydin S. Three new players in energy regulation: preptin, adropin and irisin. Peptides 2014; 56: 94-110.

19. Kumar KG, Zhang J, Gao S, Rossi J, McGuinness OP, Halem HH et al. Adropin deficiency is associated with increased adiposity and insulin resistance. Obesity (Silver Spring) 2012; 20: 1394-1402.

20. Zhang XJ, Deng YX, Shi QZ, He MY, Chen B, Qiu XM. Hypolipidemic effect of the Chinese polyherbal Huanglian Jiedu decoction in type 2 diabetic rats and its possible mechanism. Phytomedicine 2014; 15; 21 (5): 615-623.

21. Sendrayaperumal V, Iyyam Pillai S, Subramanian S. Design, synthesis and characterization of zinc-morin, a metal flavonol complex and evaluation of its antidiabetic potential in HFD-STZ induced type 2 diabetes in rats. Chem Biol Interact 2014; 219 (5): 9-17.

22. Butler AA, Tam CS, Stanhope KL, Wolfe BM, Ali MR, O'Keeffe M, St-Onge MP, Ravussin E, Havel PJ. Low circulating adropin concentrations with obesity and aging correlate with risk factors for metabolic disease and increase after gastric bypass surgery in humans. J Clin Endocrinol Metab 2012; 97 (10): 3783-3791.

23. Saraswat B, Visen PK, Patnaik GK, Dhawan BN. Anticholestatic effect of picroliv, active hepatoprotective principle of Picrorhiza kurrooa, against carbon tetrachloride induced cholestasis. Indian J Exp Biol 1993; 31 (4): $316-318$.
24. Rajesh MG, Latha MS. Preliminary evaluation of the antihepatotoxic activity of Kamilari, a polyherbal formulation. J Ethnopharmacol 2004; 91 (1): 99-104.

25. Soufi FG, Sheervalilou R, Vardiani M, Khalili M, Alipour MR. Chronic resveratrol administration has beneficial effects in experimental model of type 2 diabetic rats. Endocr Regul 2012; 46 (2): 83-90.

26. Liu YN, Jung JH, Park H, Kim H. Olive leaf extract suppresses messenger RNA expression of proinflammatory cytokines and enhances insulin receptor substrate 1 expression in the rats with streptozotocin and high-fat diet-induced diabetes. Nutr Res 2014; 34 (5): 450-457.

27. Warne JP. Tumour necrosis factor alpha: a key regulator of adipose tissue mass. J Endocrinol 2003; 177: 351-355.

28. Autuna-Puente B, Feve B, Fellahi S, Bastard JP. Adipokines: the missing link between insulin resistance and obesity. Diabetes Metab 2008; 34: 2-11.

29. Lovren F, Pan Y, Quan A, Singh KK, Shukla PC, Gupta M, AlOmran M, Teoh H, Verma S. Adropin is a novel regulator of endothelial function. Circulation 2010; 14; 122: 185-192.

30. Kataoka T, Hotta Y, Maeda Y, Kimura K. Assessment of androgen replacement therapy for erectile function in rats with type 2 diabetes mellitus by examining nitric oxide-related and inflammatory factors. J Sex Med 2014; 11 (4): 920-929.

31. He J, Yang Z, Yang H, Wang L, Wu H, Fan Y, Wang W, Fan X, Li $\mathbf{X}$. Regulation of insulin sensitivity, insulin production, and pancreatic $\beta$ cell survival by angiotensin-(1-7) in a rat model of streptozotocin-induced diabetes mellitus. Peptides 2015; 7; 64C: 49-54.

32. Kuloglu T, Aydin S. Immunohistochemical expressions of adropin and inducible nitric oxide synthase in renal tissues of rats with streptozotocininduced experimental diabetes. Biotech Histochem 2014; 89 (2): 104-110.

Received May 8, 2015. Accepted June 26, 2015. 